\title{
OPTIMIZATION OF NUMERICAL SIMULATIONS OF GRAVITY CASTING OF DUCTILE IRON CASTINGS
}

\author{
${ }^{1}$ Karel GRYC, ${ }^{1}$ Ladislav SOCHA, ${ }^{1}$ Jana SVIŽELOVÁ, ${ }^{2}$ Tomáš PRÁŠIL, ${ }^{2} I v a n$ HOTOVÝ, \\ ${ }^{2}$ Pavel ČIZŽEK, ${ }^{2} J a n$ ŠTEFÁNEK \\ ${ }^{1}$ Institute of Technology and Business in České Budějovice, České Budějovice, Czech Republic, EU, \\ gryc@mail.vstecb.cz, socha@mail.vstecb.cz, svizelova@mail.vstecb.cz, \\ ${ }^{2}$ MOTOR JIKOV Slévárna a.s. České Budějovice, Czech Republic, EU, \\ tprasil@migroup.cz, ihotovy@misl.cz,.pcizek@misl.cz,jstefanek@misl.cz
}

https://doi.org/10.37904/metal.2021.4094

\begin{abstract}
This paper is devoted to the presentation of initial results focused on the optimization of numerical simulations of gravity casting of ductile iron castings into non-permanent bentonite molds. Numerical simulations were performed focused on the course of filling the mold and solidification of the casting by simulation SW ProCAST. The proportions of pearlite and ferrite phases, graphite nodularity and hardness were obtained. The input parameters were set to fit the simultaneously realized experimental operating melts. Macroscopic defects, metallographic structure and hardness were verified in selected sections of test castings. The data obtained from metallographic analysis and hardness were used to verify the results of numerical modeling. The comparison of the results shows a good agreement between the real casting and the numerical simulation.
\end{abstract}

Keywords: Ductile iron, microstructure, numerical simulation, model validation, ProCAST

\section{INTRODUCTION}

Cast irons are materials with a wide range of properties and application. The main factors influencing mechanical properties of cast iron are graphite morphology, metal matrix composition and casts defects [1-4]. Graphite fit can appear in several modifications in cast irons - lamellar graphite (GJL), nodular graphite (GJS), compacted graphite (GJV), flake graphite (GJM) [5]. From the mechanical properties' viewpoint, the graphite nodules are the most favourable modification (see Figure 1), since it eliminates graphite flakes impact effect. Mechanical properties of the remaining cast iron types range from GJL to GJS [2]. The metal mass composition depends on many factors, e.g. on chemical composition and cooling rate. However, the basic metal mass of unalloyed cast iron consists most often of ferrite and pearlite $[2,6]$. Ferrite is soft, ductile, with low strength; in cast iron it is a ductility carrier. By contrast, pearlite is a carrier of higher strength and hardness.

Cast iron with nodular graphite must have mechanical properties specified by the standard [7]. Therefore, it is desirable to achieve a certain material structure that depends on many factors [2,6]. E.g., the pearlite and ferrite

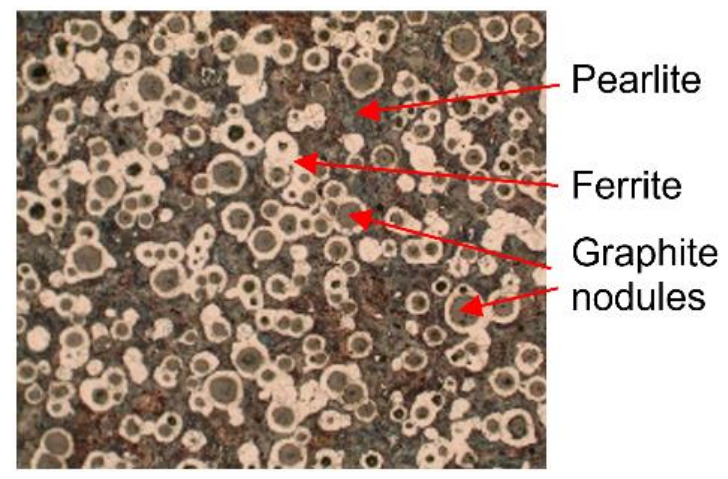

Figure 1 Example of structure of cast irons fith nodular graphite proportion depends, to a large extent, on the cooling rate which is influenced by the cast wall thickness and by the mold cooling ability [8-10]. Chemical composition is rather important from the viewpoint of mechanical 
properties as well defects formation in a cast $[2,8,11]$. Chemical composition of cast irons with graphite nodules is not specified by a standard, therefore it depends on the manufacturer's experience.

Cast iron properties can be determined by tests of standardized samples with prescribed parameters [7]. Another method is, for example, numerical simulations application. Numerical simulation does not require manufacturing of a physical cast for determination of a material/cast properties and, after the model successful validation, it can be an efficient tool for relatively fast specification of changes in the cast structure at various technological parameters adjustment (e.g., chemical composition of the material, casting temperature, cooling ability of the mold, thermal processing, etc.). To a certain extent, it saves time and finance spent on samples or trial casts manufacturing.

Many products for metallurgical processes simulation exist on the market now. One of them is the ProCAST simulation software [12] for foundry applications. ProCAST that operates with the final elements method provides an extensive system of modules and foundry tools. Besides the basic applications, i.e. calculation of filling, solidification and stress conditions, it provides, e.g., also the possibility of microstructure, porosity, segregation and mechanical properties of materials prediction, as well as solution of specific processes, like lost foam, centrifugal, continuous casting [13], etc.

Currently, the Environmental Research Department of the Institute of Technology and Business in České Budejovice conducts a research that is focused on optimization of ductile cast iron casting. For this purpose, operational heats are realized in the MOTOR JIKOV Slévárna a.s., the aim of which is to assess the influence and efficiency of the designed and modified technological processes of production, secondary metallurgy, casting and thermal processing of ductile iron casts. It also includes numerical simulation in the SW ProCAST, focused on the melt properties, on setting the conditions for casting, solidification and cooling of ductile iron casts; the objective is to identify and prevent problem in the designed production technology which might result in defects occurrence. The paper presents the results of primary numerical simulations, the target of which was adjustment of the numerical model and achieving of the highest possible compliance with a real cast structure and properties. Data from metallographic analysis of a particular cast, casted within trial heats, were used for the numerical model results verification.

\section{EXPERIMENTAL PROCEDURE}

The study proper was focused on a HANDLE 1265 type casting (see Figure 2) that is a part of the gear mechanism for passenger cars. The casts are casted gravitationally into bentonite molds. A non-permanent mold for gravitational casting includes 6 casts arranged as shown on Figure 2. The cast is manufactured from the EN-GJS-450-10 material; its general chemical composition is specified in Table 1.

Table 1 Chemical composition of the EN-GJS-450-10 material (wt. \%)

\begin{tabular}{|c|c|c|c|c|c|}
\hline $\mathrm{C}$ & $\mathrm{Si}$ & $\mathrm{Mn}$ & $\mathrm{P}$ & $\mathrm{S}$ & $\mathrm{Cu}$ \\
\hline 3.85 & 2.62 & 0.21 & 0.05 & 0.01 & 0.04 \\
\hline
\end{tabular}

Computational geometry (i.e., a mold cavity, that means casts including the gating system, filter and risers) was created for numerical simulations purposes; its size corresponded to a real mold used in operating conditions. Thus, prepared geometry was then covered by a 3D computational grid with 2542841 elements. To provide an idea concerning the structure, Figure 3 shows an example of the computational geometry surface and 3D mesh. 
A gravitational vector was further defined in the direction of the negative $Y$ axis, casting temperature, conditions of heat transfer, heat transfer coefficients (HTC) between the gating system components and boundary conditions for the correct course of filling and solidification. Materials of individual components of the gating system are specified in Table 2. The mold temperature of $30{ }^{\circ} \mathrm{C}$ and bentonite mixture humidity of $3,6 \%$ were used for the calculation purposes. The calculation was carried out using the Thermal module and Pseudobinary Microstructure module.

Within the numerical model setting optimization, 14 partial simulation variants were realized, with adjusted solvers' parameters. The geometry, computational mesh, materials, initial and boundary conditions of the process were not changed across the variants. The following text presents the variant with the highest compliance with the analyzed casting properties.
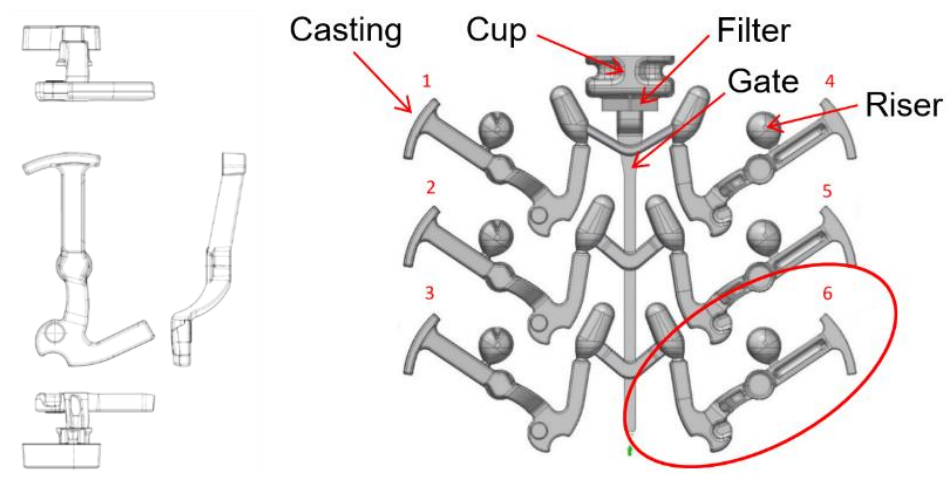

Figure 2 Drawing of a HANDLE 1265 casting and casts arrangement in the mold
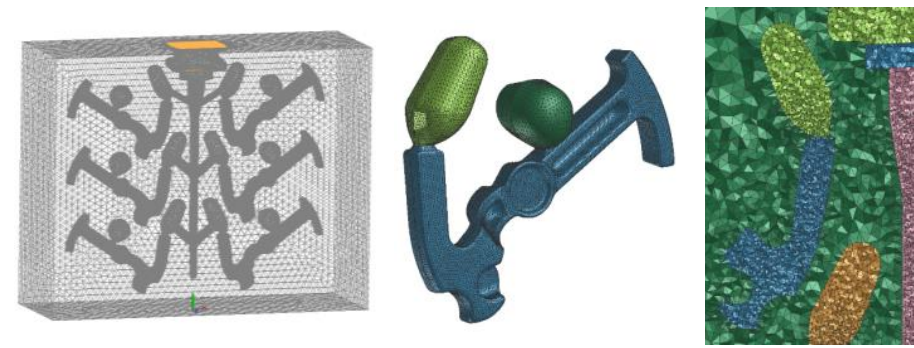

Figure 3 Geometry of a mold and computational mesh

Table 2 Materials of individual parts of a gating system

\begin{tabular}{|c|c|c|c|c|c|c|}
\hline Name & Casting & Riser & Gate & Cup & Mold & Filter \\
\hline Material group & Alloy & Alloy & Alloy & Alloy & Mold & Filter \\
\hline Material & $\begin{array}{c}\text { EN-GJS-450- } \\
10\end{array}$ & $\begin{array}{c}\text { EN-GJS-450- } \\
10\end{array}$ & $\begin{array}{c}\text { EN-GJS-450- } \\
10\end{array}$ & $\begin{array}{c}\text { EN-GJS-450- } \\
10\end{array}$ & Green Sand & 10 PPI \\
\hline
\end{tabular}

\section{MODEL VALIDATION}

The numerical model validation was carried out with application of results of a metallographic analysis of samples taken from casts produced within operational heats. Potentially problematic points in the casts were specified on the basis of numerical simulations results and after consultation with the operating partner for the purposes of microstructural and mechanical properties and porosity occurrence evaluation. Sections were situated in the relevant places and samples were taken from them for assessment of the pearlite/ferrite portion and of graphite nodularity according to the ČSN EN ISO 945-1 standard [14], as well as of Brinell hardness according to the ČSN EN ISO 6506-1 standard [15] and porosity presence. The relevant properties appeared to be suitable for the numerical model validation, since they are available within

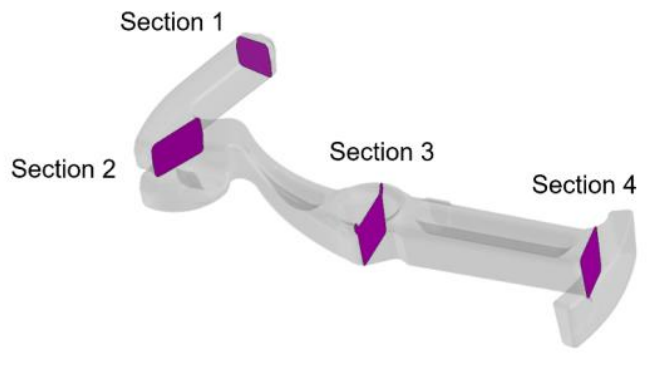

Figure 4 Positions of samples taken 
the SW ProCAST numerical simulation results. Each of the samples/sections was then analyzed in 9 points. Section planes were defined in the SW ProCAST according to the section's positions on a cast (see Figure 4). Then the position of points for data export was defined approximately on individual sections on the basis of the points positions on the relevant sample. Figure 5 shows the points positions for microstructural and mechanical properties analysis. The specified properties analysis was carried out for all the 6 casts located in the mold (Figure 2). Considering the analysis scope and the data amount, the cast No. 6 was selected for the results presentation (on Figure 2 marked in red).

\section{RESULTS AND DISCUSSION}
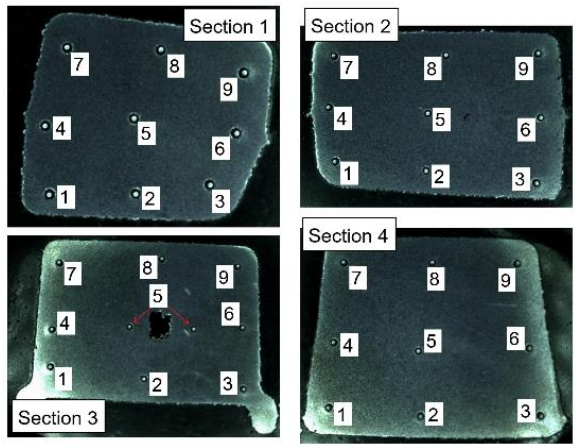

Figure 5 Positions of points for Brinell hardness analysis

Figures 6 and 7 show comparison of results of the numerical simulations and of the metallographic analysis of the relevant properties in individual points of the section. Figure 6 shows comparison of results of the metallographic analysis which assessed the ferrite and pearlite portion and graphite nodularity with the numerical simulations results. Brinell hardness was compared as well. With regard to the assessment scope, for information we present complete analysis of sections 2 and 4 where porosity occurrence was found.
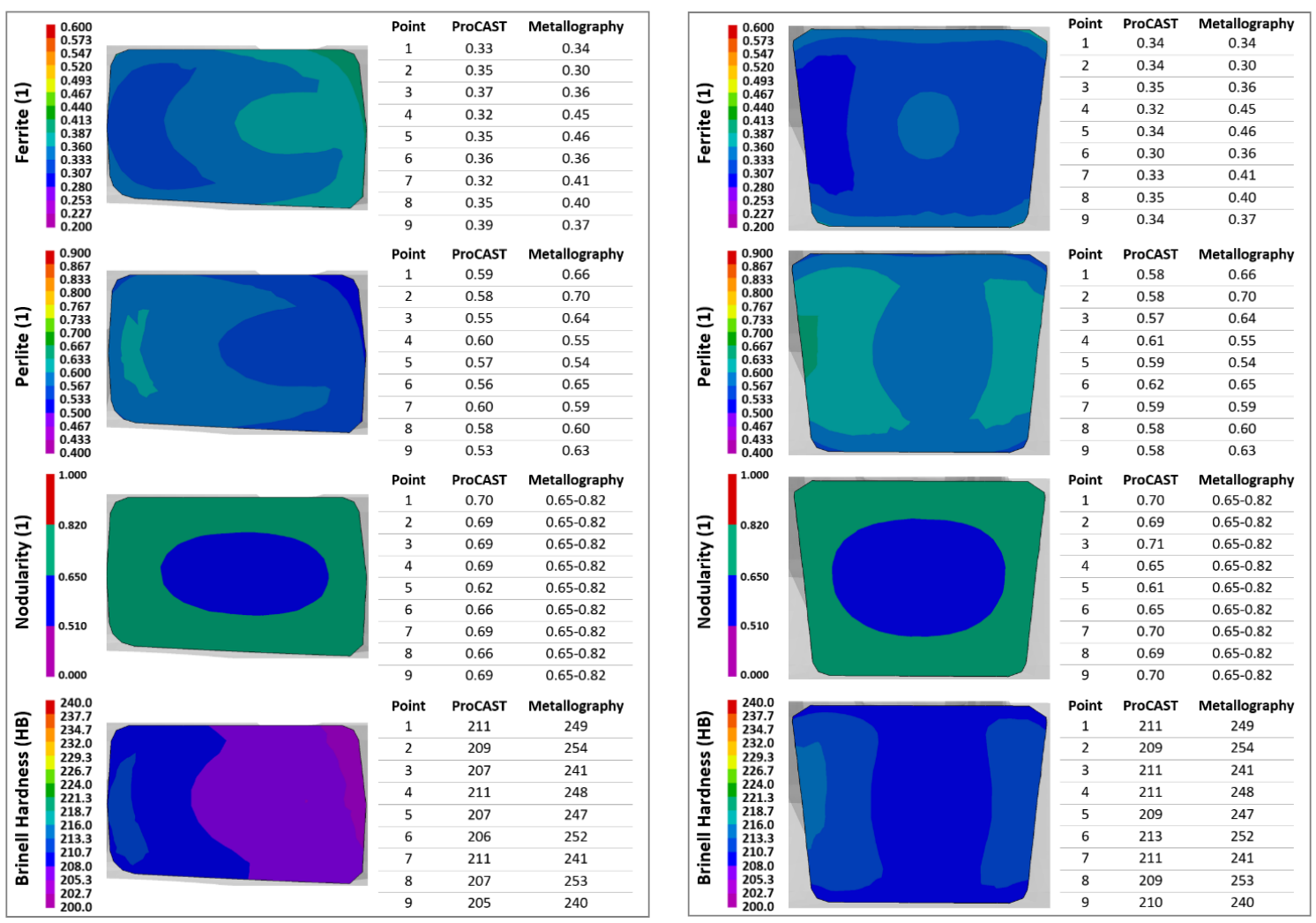

Figure 6 Comparison of the numerical simulation results to the metallographic analysis

(left: Section 2, right: Section 4)

It is necessary to draw attention to the fact that while values to the ferrite and pearlite portion from metallographic analyses are calculated to 1 or, as the case may be, to $100 \%$, the sums of the ferrite and pearlite portion values exported from SW ProCAST do not correspond to it, because postprocessing stores separately the graphite values (primary, secondarily discharged, total). Therefore, it can be expected that 
compared to the metallographic analysis, in case of simulation the pearlite portion is slightly reduced by the value corresponding to the graphite portion in the structure (ca 7-9\%).

Based on the facts specified and, on the results, obtained it can be stated that the Microstructure model results comply relatively well with the metallographic analysis. Hardness was the only exception; it was undervaluated within the simulation. Attention shall be paid to this problem within further optimization of the calculation.

Figure 7 shows comparison of samples taken from a cast, with porosity predicted by the SW ProCAST. It is clear that a very good compliance of results has been achieved. Porosity occurred in the cast in the area of sections 2 and 4 . It was also predicted by the SW ProCAST in the same areas. The porosity area range was in good compliance, too.
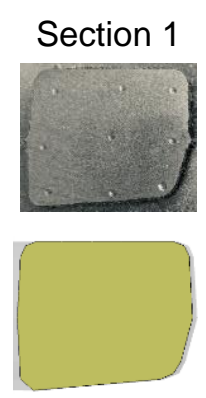
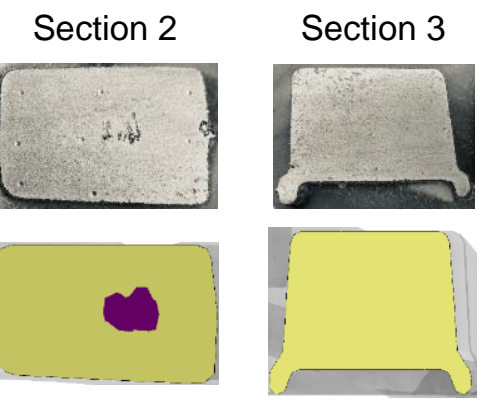

Figure 7 Porosity prediction

\section{CONCLUSION}

Primary numerical simulations of casting and solidification of a HANDLE 1265 type of ductile cast iron cast have been introduced within the article submitted; they were realized within optimization of the relevant cast production technology. Knowledge obtained within the numerical simulations' solution can be summarized into the below points:

- $\quad$ A CAD geometry has been created for the numerical simulations' requirements; subsequently, it was covered by a 3D computational mesh.

- The calculation itself was realized by the Thermal module and the Pseudo-binary Microstructure module, which are comprised in SW ProCAST.

- 14 partial simulation variants were realized; within them the solvers' setting was tested with the aim to obtain the best possible compliance of results with a real cast.

- The model was validated through a particular cast produced within trial operational heats. Samples were taken from the relevant cast which were analyzed metallographically with the aim to determine the portion of ferrite and pearlite and graphite nodularity. Brinell hardness was measured as well.

- The numerical simulation results comparison with metallographic analysis and hardness measuring was carried out within the verification. Very good compliance was reached in the porosity area. ProCAST predicted porosity occurrence in those locations where it also appeared in reality in the cast. The porosity location was in compliance, as well as its scope. Good compliance was reached also in the area of pearlite and ferrite portion and the graphite nodularity.

- Within the simulation, Brinell hardness values were lower than hardness determined by measuring by the order of several tens of points.

The calculation optimization will continue within further solution of numerical simulations, with the aim to obtain better compliance regarding the hardness values. After the setting adjustment, the numerical simulations will serve for testing of various technological parameters impacts on casts quality, in particular from the viewpoint of porosity elimination and obtaining of the required mechanical properties of casts.

\section{ACKNOWLEDGEMENTS}

The work was created under the support of the Czech Ministry of Industry and Trade within the frame of the program TRIO in the solution of the project reg. no. FV40346 "Research and Development of 


\section{Advanced Technological Processes for the Production of Cast Iron Castings with the Implementation of 3D scanning into the Quality Management Process". The authors thank the MECAS ESI team for preparing master studies and strong technical support in the ProCAST software for the above mentioned project.}

\section{REFERENCES}

[1] LAINE, J., JALAVA, K., VAARA, J., SOIVIO, K., FRONDELIUS, T., ORKAS, J. The Mechanical Properties of Ductile Iron at Intermediate Temperatures: The Effect of Silicon Content and Pearlite Fraction. International Journal of Metalcasting. [online]. 2021, vol. 15, iss. 2, pp. 538-547. ISSN 1939-5981. Available from: https://doi.org/10.1007/s40962-020-00473-8.

[2] PERO-SANZ ELORZ, J. A., GONZÁLEZ D. F., VERDEJA L. F. Physical Metallurgy of Cast Irons. Cham: Springer, 2018. ISBN 798-3-319-97312-8.

[3] VASKOVA, I., HRUBOVCAKOVA, M., MALIK, J., EPERJESI, S. Influence of technological parameters of furane mixtures on shrinkage creation in ductile cast iron castings. Archives of Metallurgy and Materials. [online]. 2014, vol. 59, no. 3, pp. 1037-1040. ISSN 1733-3490. Available from: https://doi.org/10.2478/amm-2014-0174.

[4] VASKOVA, I., CONEV, M., HRUBOVCAKOVA, M. The influence of using different types of risers or chills on shrinkage production for different wall thickness for material EN-GJS-400-18LT. Archives of Foundry Engineering. [online]. 2017, vol. 17, no. 2, pp. 131-136. ISSN 2299-2944. Available from: https://doi.org/10.1515/afe-2017-0064.

[5] ČSN EN 1560. Foundry - Designation system for cast iron - Material symbols and material numbers. Praha: Czech Office for Standards, Metrology and Testing, 2012, p. 16.

[6] BERNS, H., THEISEN W. Ferrous Materials: Steel and Cast Iron. Berlin: Springer, 2008. ISBN 978-3-540-718475.

[7] ČSN EN 1563. Founding - Spheroidal graphite cast irons. Praha: Czech Office for Standards, Metrology and Testing, 2019, p. 40.

[8] SAZEGARAN, H., TEIMOORI, F., RASTEGARIAN, H., NASERIAN-NIK, A.M. Effects of aluminum and copper on the graphite morphology, microstructure, and compressive properties of ductile iron. Journal of Mining and Metallurgy, Section B: Metallurgy. [online]. 2021, vol. 57, no. 1, pp. 145-154. ISSN 1450-5339. Available from: https://doi.org/10.2298/JMMB191224006S.

[9] BEŇO, J., LICHÝ, P., KROUPOVÁ, I., RADKOVSKÝ, F. Influencing of foundry bentonite mixtures by binder activation. Metalurgija. 2016, vol. 55, iss. 1, pp. 7-10. ISSN 0543-5846.

[10] HRUBOVCAKOVA, M., BARTOSOVA, M., VASKOVA, I., DZUPKOVA, M. BUL'KO, B., DEMETER, P., BARICOVA, D. Influence of mixer type and treatment time on strength properties of furan compounds. In: METAL 2019: 28TH INTERNATIONAL CONFERENCE ON METALLURGY AND MATERIALS. Ostrava: TANGER, 2019, pp. 211-216. ISBN 978-80-87294-92-5.

[11] GONZÁLEZ-MARTÍNEZ, R., SERTUCHA, J., LACAZE, J. Effects of cobalt on mechanical properties of high silicon ductile irons. Materials Science and Technology. [online]. 2020, vol. 36, iss. 12, pp. 1292-1300. ISSN 0267-0836. Available from: https://doi.org/10.1080/02670836.2020.1777509.

[12] ProCAST. ESI Group [online]. [viewed: 2021-6-18]. Available from: https://www.esi-group.com/products/casting.

[13] SVIŽELOVÁ, J., TKADLEČKOVÁ M., MICHALEK K., STROUHALOVÁ M. Influence of Casting Speed on Centerline Porosity Formation in Continuously Cast Round Steel Billets. In: METAL 2017: 26TH INTERNATIONAL CONFERENCE ON METALLURGY AND MATERIALS. Ostrava: TANGER, 2017, pp. $235-240$. ISBN 978-80-87294-79-6.

[14] ČSN EN ISO 945-1. Microstructure of cast irons - Part 1: Graphite classification by visual analysis. Praha: Czech Office for Standards, Metrology and Testing, 2020, p. 68.

[15] ČSN EN ISO 6506-1. Metallic materials - Brinell hardness test - Part 1: Test method. Praha: Czech Office for Standards, Metrology and Testing, 2015, p. 20. 